\title{
Roles and Responsibilities Relating Land Agreement Official of Liability Provision of Rights With Mudharabah in Islamic Bank
}

\begin{abstract}
Yoni Oktaviani ${ }^{1}$ and Akhmad Khisni ${ }^{2}$
Abstract. This research examines the concept of binding guarantee of the rights to land in accordance with laws and regulations in Indonesia and Islamic law; as well as the roles and responsibilities associated with APHT PPAT in the contract of Mudharabah in Islamic Bank. The method used in this research is normative. The results showed that APHT can not be used on the contract of Mudharabah and Islamic law has its own security institutions, namely Rahn. Roles and responsibilities of PPAT associated with APHT in the contract of Mudharabah in Islamic Bank will be explained by Act No. 4 of 1996, Act No. 21 of 2008, Government Regulation No. 37 of 1998, as amended by Regulation No. 24 of 2016, PERKABAN No. 1 of 2006, as amended by PERKABAN No. 23 of 2009 and Theory of Accountability.

Keywords: Responsibility; Land Agreement Official; Mudharabah System.
\end{abstract}

\section{Introduction}

One of a form of legal protection to the Islamic banking in reducing the risk of financing that allowed the bank to require security to those customers who want to apply for financing. As stipulated in Act No. 21 of 2008 concerning Islamic Banking, National Sharia Board Fatwa Indonesian Ulama Council (DSN-MUI) No. 07 / DSN-MUI / IV / 2000 on Mudharabah (Qiradh), DSN-MUI Fatwa Number 74 / DSN-MUI / I / 2009 on Islamic Assurance and Indonesian Bank Regulation (PBI) No. 7/46 / PBI / 2005 regarding the Agreement of Collection and Distribution of Funds for Banks Conducting Business Based on Sharia Principles.

To ensure that the collateral provided will be able to guarantee the repayment of the financing of the collateral submitted by the debtor should be made binding. And, as a follow up of the provision of collateral, particularly land rights, is poured into a form Agreement Granting Mortgage (APHT), as such and regulated Act No. 4 of 1996 on Mortgage of Land along with the Goods Dealt With Land (Act Mortgage: UUHT). ${ }^{3}$ APHT made in advance and in front of the Land Agreement Official (PPAT), as stated in Article 10 paragraph (2) UUHT.

According to Sutan Remy Sjahdeini, mudharabah did not constitute debts agreement but an agreement regarding joint efforts with the parties. ${ }^{4}$

With any difference in principle between mudharabah and then APHT the credit agreement can not be used for binding guarantee in the form of land rights on mudharabah. Although there has been no Act No. 21 of 2008 concerning Islamic Banking which also require additional collateral object or thing but it turns out in the guarantee were not still using

\footnotetext{
${ }^{1}$ Master of Notary's Student Sultan Agung Islamic University (UNISSULA) Semarang email yonioktaviani@yahoo.com

2 Lecturer of Faculty of Law UNISSULA

3 Habib Adjie dan Muhammad Hafidh 2014 Akta Perbankan Syariah yang Selaras Pasal 38 UUJN-P Edisi Revisi First Edition Semarang: Pustaka Zaman p. 70.

4 Sutan Remy Sjahdeini 1999 Perbankan Islam dan Kedudukannya dalam Tata Hukum Perbankan Indonesia First Edition Jakarta: Pustaka Utama Grafiti p. 34
} 
UUHT APHT and sharia is not well. ${ }^{5}$

The concept of binding guarantee in the form of land rights in Indonesia according to the Positive Law and Islamic Law in principle clearly different in terms of resources or legal basis. However, Islamic banking is still used as a binding guarantee Encumbrance over land rights. This poses a problem for the implementation of mortgage insurance agency is based on the positive law of Indonesia whereas every activity must be based on the provision of Islamic banking or Islamic principles.

Based on the above description can be formulated problems: First, how the concept of binding guarantee of the rights to land in accordance with Regulation Legislation in Indonesia and Islamic law? Second, how the roles and responsibilities of the Land Agreement Official (PPAT) related to Granting Mortgage Agreement (APHT) in the contract of Mudharabah Islamic Bank?

\section{Research Methods}

The method used in this research is normative and descriptive-qualitative. This research will use the primary legal materials, secondary and tertiary. Primary legal materials such as the Book of the Civil Law (Civil Code), Act No. 7 of 1992 as amended by Act No. 10 of 1998, Act No. 4 of 1996 on Mortgage of Land along with Repository Objects Relating to Land, Act No. 21 of 2008 concerning Sharia Banking Regulation No. 37 of 1998 on the Regulations Title Agreement official Land, Indonesian Bank Regulation (PBI) No. 7/46 / PBI / 2005 regarding the Agreement of Collection and Distribution of Funds for Banks Conducting Business Based on principle Sharia, National Sharia Board Fatwa Indonesian Ulama Council (DSN-MUI) No. 07 / DSN-MUI / IV / 2000 on Mudharabah (Qiradh), DSNMUI Fatwa No. 74 / DSN-MUI / I / 2009 on Islamic Assurance, DSN-MUI No. 25 / DSN-MUI / III / 2002 Rahn, DSN-MUI No. 68 / DSN-MUI / III / 2008 Rahn Tasjily and DSN-MUI No. 92 / DSN-MUI / IV / 2014 on Accompanied financing Rahn (At-Tamwil Al-Mautsuq Bi AlRahn). Secondary law is primarily the books related to the concept of binding guarantee of the rights to land under Regulation Legislation in Indonesia and Islamic law, and also books relating to the roles and responsibilities of PPAT associated with APHT in the contract of Mudharabah Bank Sharia. Tertiary legal materials in this study are: Big Indonesian Dictionary (KBBI) and Law Dictionary.

Data collected will be analyzed, studied and discussed in order to do a comparison between the object under investigation so that it can be deduced from it. In the end, the results of these studies will be presented descriptively and qualitatively.

\section{Results And Discussion}

\subsection{Guarantees Against Binding Raft of Land According to the Regulation Legislation in Indonesia and Islamic Law}

The existence of credit guarantees (collateral) is a requirement in order to minimize the risk of banks to extend credit. ${ }^{6}$ In terms of guaranteeing repayment of the bank loans granted against collateral or guarantees submitted by the debtor should be made binding. ${ }^{7}$ In terms of the binding guarantees the rights to land, with the entry into force of UUHT on April 9, 1996, Encumbrance is the only institution guarantee rights to land in the National Land Law is written. ${ }^{8}$

\footnotetext{
${ }^{5}$ Habib Adjie dan Muhammad Hafidh Akta ... op. cit. p. 71.

${ }^{6}$ Budi Untung 2011 Kredit Perbankan di Indonesia Edisi Kedua Yogyakarta: Andi p. 60.

${ }^{7}$ Ibid. p. 66

${ }^{8}$ Boedi Harsono 2008 Hukum Agraria Indonesia Sejarah Pembentukan Undang-Undang Pokok Agraria Isi dan Pelaksanaanya Jilid 1 Hukum Tanah Nasional Jakarta: Djambatan p. 416.
} 
Encumbrance is a guarantee of land rights to a particular debt settlement that gives precedence to the position of certain creditors to other creditors. ${ }^{9}$ UUHT is the enactment of legislation governing the imposition of land rights is Chapter 21, Book II of the Civil Code, relating to mortgage and Credietverband in Staatsblad 1908-542 as amended by Gazette 1937-190. Both of these provisions is not valid because it is no longer appropriate to the needs of lending activities in Indonesia because the old legislation that can be made the object of mortgage and credietverband only property rights, the right to cultivate, and the right to build, while the UUHT, which became the object of rights dependent not only a third of the land rights but coupled with the right to use the land and rights to land and building. ${ }^{10}$

Subject security right under Article 8 to Article 9 UUHT. In the second chapter it is determined that the law would be subject to the imposition of mortgage is the giver of rights holders of mortgage and dependents. Giver of security rights can be individual or legal entity, which has the authority to take legal actions against the object of mortgage. Holders of mortgage consists of individuals or legal entities, who serves as the indebted. Usually in practice, the giver of mortgage called a debtor, that is lending money at banking institutions encumbrance while the receiver is called the creditor, namely the person or legal entity who serves as the indebted. ${ }^{11}$

The concept of binding guarantee in the form of land rights in accordance with Islamic law similar legal constructions such Encumbrance is Rahn. Rahn is holding one property of the borrower or customer (rahin) as collateral (marhun) on loans receives (marhun bih). The detained goods have economic value. Thus, the parties hold a guaranteed to be able to take back the whole or part of its receivables. ${ }^{12}$ According to the AA Bashir, Rahn is an agreement hold for something as outstanding debts or make something valuable objects in the view of Personality 'as the dependents marhun bih so with outstanding debts in the whole or part of the debt is acceptable. ${ }^{13}$

According to Muhammad, ${ }^{14}$ Rahn included in the category of complementary contract in Islamic Banking Operations Products in Indonesia whose purpose is to guarantee repayment to the bank to provide financing. Pawned goods shall meet the following criteria: Owned customers themselves; Obviously the size, nature and its value is determined based on the real value of the market; and can be controlled but can not be used by the bank.

Sasli Rais asserted that in civil law, lien applies only to moving objects while in Islamic law, Rahn apply to all objects or property, whether the property movable or immovable. ${ }^{15}$

The term of Rahn ${ }^{16}$ in the Quran Al-Baqarah verse 283 which reads: "And when you're on the way you do not get a scribe then let no dependents goods held (by the indebted) ..."

That verse explicitly mentions "dependents goods held (by the indebted)". In the financial world, dependents goods commonly known as security (collateral) or object pawnshop.

Sethe other, there is also a cornerstone of Sharia Rahn in Al-Hadith ie 'A'ishah said that the

\footnotetext{
${ }^{9}$ Adrian Sutedi loc. cit.

${ }^{10}$ Salim HS. 2004 Perkembangan Hukum Jaminan di Indonesia Edisi Pertama Cetakan Pertama Jakarta: Raja Grafindo Persada p. 95.

${ }^{11}$ Ibid. p.103-104.

${ }^{12}$ Muhammad Shafi Antonio Bank ... op. Cit. p. 128.

13 A. A. Basyir 2005 Hukum Islam tentang Riba Utang-Piutang Gadai dikutip dari Sasli Rais Pegadaian Syariah: Konsep dan Sistem Operasional Suatu Kajian Kontemporer (Jakarta: UIPress p. 38.

${ }^{14}$ Muhammad Management Bank... op.cit. p. 101.

${ }^{15}$ Sasli Rais Pawn ... op.cit. P 47.

${ }^{16}$ Muhammad Shafi Antonio Bank ... op. Cit. P. 128-129.
} 
Prophet buy food from a Jew, and offers him the armor. "(Bukhari no. 1926, Kitab al-Buyu, and Muslim). Anas said, "The Messenger mortgaged his armor to a Jew in Medina and took away the grain for his family." (Bukhari no. 1927, Kitab al-Buyu, Ahmad, Nasa'i and Ibn Majah)

From the description of the Rahn, means that in Islamic law has its own security institutions that can be used on moving objects or object is not moving. DSN-MUI Fatwa governing Rahn is the National Sharia Board Fatwa No. 25 / DSN-MUI / III / 2002. The fatwa is based on that loan by mortgaging the goods as collateral in the form of Rahn allowed. ${ }^{17}$ National Sharia Board of the Indonesian Ulama Council (DSN-MUI) has even given the fatwa specifically regulates Rahn that can be used on a stationary object such as land, namely, the National Sharia Board Fatwa No. 68 / DSN-MUI / III / 2008 Rahn Tasjily, In the first part of the general provisions in the decree stated that:18"Rahn Tasjily - also called Ta'mînî Rahn, Rahn Rasmi or Hukmi - is a guarantee in the form of goods on the debt, with the agreement that were submitted to the insured (murtahin) whereas only valid proof of ownership of physical goods such guarantees (marhûn) remain in control and the utilization of the guarantor (Râhin). "

In connection with mudharabah which is discussed in the research, specifically applicable DSN-MUI Fatwa No. 92 / DSN-MUI / IV / 2014 on Financing Accompanied by Rahn (AtTamwil Al-Mautsuq $\mathrm{Bi}$ Al-Rahn). The provisions in this fatwa applies to all forms of financing / distribution of funds of Islamic Financial Institution (LKS) which may be secured by collateral $($ Rahn $) .{ }^{19}$

However, in the practice of Islamic banking in Indonesia, a formal law that governs the legal relationship between Islamic banks and customers (financing and depositors) are governed by the Civil Code, which includes the guarantee ${ }^{20}$ (Not referring to the fatwas mentioned above). As stated Faturrahman Djamil that given binding assurances for Islamic banks until now there is no special arrangement, the implementation of binding assurances made by Islamic banks is to enact legislation on the existing conventional security institutions. $^{21}$

The existence of and Rahn Tasjily based DSN-MUI, should be a source of law is the special treatment for binding guarantees on Islamic banking, especially the binding guarantees the rights to land. Islamic banking requires a legislation that is complete and technically set binding guarantee of the right to land, as well as the presence of security institutions Encumbrance on conventional banking. Therefore, the concept of binding guarantees in Rahn Tasjily and is expected to be arranged in an Act in order to become the legal basis for security institutions over land rights in Islamic banking.

With the birth of the Act which specifically regulates the binding guarantees the rights to land for Islamic banking then the element kesyariahan in any contract of Islamic banking can be realized and fulfilled perfectly so no need to use APHT as a binding guarantee of the right to land use conventional banking, especially mudharabah.

\subsection{Role and Responsibilities of Land Agreement Official (PPAT) Relating to Granting Mortgage Agreement (APHT) on Mudharabah in Islamic Banking}

\footnotetext{
${ }^{17}$ Tim Penyunting Erlangga 2014 Himpunan Fatwa Keuangan Syariah Dewan Syariah Nasional MUI (Jakarta: Erlangga p. 738.

${ }^{18}$ Ibid. p. 744.

${ }^{19} \mathrm{http}: / /$ www.khafidzt.ga/2015/03/92dsn-muiiv2014-pembiayaan-yang-disertai-rahn.pdf Access the July 282016.

20 Prihati Yuniarlin and Dewi Nurul Musjtari Hukum... op. cit. p. 179.

${ }^{21}$ Faturrahman Djamil Penyelesaian... op. cit. p. 41.
} 
In the practice of Islamic banking, finance Mudharabah is usually followed by the imposition of security rights over land rights secured by the customer to the Islamic banks were then poured into a form Agreement Granting Mortgage (APHT), as such and regulated Act No. 4 of 1996 (UUHT ) $)^{22}$ yang made in advance and in front of the Land Agreement Official (PPAT).

PPAT, according to article 1 of Government Regulation No. 37 of 1998 is the public official who is authorized to make the agreements of authenticity regarding certain legal actions regarding land rights or Top Properties Unit Flats.

In Article 53 PERKABAN Number 1, 2006, stated that:

- Company Agreement PPAT agreement made by filling out forms available in full accordance with the instructions of filling.

- Fill blank agreement in order PPAT agreement referred to in paragraph (1) shall be conducted in accordance with the incident, the status and the data is correct and supported by appropriate documents legislation.

Based on contents of the article, it is the role PPAT agreement just filling out forms that have been created and published by the Indonesian National Land Agency (BPN RI) and has been the public proclamation that the Mudharabah contract may be followed by APHT as agreement bail. ${ }^{23}$

In terms of making APHT on Mudharabah contract by PPAT then APHT may become null and void due to non-fulfillment of the conditions required by the Act. As explained in the General Explanation UUHT numbers (8) that: "Therefore Encumbrance by its nature is a followup or accessoir on a receivable particular, based on a treaty debts or other agreement, then the birth and existence is determined by the presence of receivables guaranteed repayment. "

This is certainly legal consequences to the bank be unable to execute collateral such as land rights if the debtor, in this case mudharib, can not meet its obligations under the terms of achievement of the agreement or in the contract or in the law termed engagement with defaults. If it continues to do so would be detrimental to the Islamic banking especially if the debtor better know and understand the issues.

Against violation or negligence in fulfilling the various provisions of the execution of their duties, respectively. In addition to administrative sanctions mentioned above, if it meets the necessary requirements, are concerned they may be sued in civil and / or criminal prosecuted."

PPAT that has made APHT on Mudharabah contract of Islamic banks should be accountable to civil as described above that the action was contrary to UUHT who explained that the agreement should be subject of an agreement APHT debts. Civil liability in the field can be seen are nominally set forth in Articles 1365 and 1366 of the Civil Code.

\section{Closing}

\subsection{Conclusion}

- Binding concept guarantees over land rights by using Mortgage poured into APHT form can not be used on a principal agreement in the form of Mudharabah. Because, based on a common explanation Mortgage UUHT that by its nature is a followup or accessoir at a certain receivables, based on a debt-receivable agreement.

- Binding concept guarantee in the form of land rights in accordance with Islamic law similar legal constructions such Encumbrance is Rahn.

- PPAT agreement just filling out forms that have been created and published by the

${ }^{22}$ Adjie Habib and Mohammed Hafidh loc. cit.

${ }^{23}$ Faturrahman Djamil Penhyelesaian ... op.cit. P. 41. 
Indonesian National Land Agency (BPN RI) and has been the public that the Mudharabah contract may be followed by APHT as agreement bail. PPAT who had made APHT on Mudharabah contract in Islamic banks must be held accountable to civil or criminal law because it has resulted in a loss for the Islamic banks, as explained in section General Explanation UUHT number 11 confirmed the presence of administrative sanctions.

\subsection{Suggestion}

As for suggestions that wants to convey is that researchers;

- Islamic banking should the in-depth analysis in fiqh mu'amalah in any Islamic Banking Operations products that will be released so as not to cause problems and losses in the future at Islamic Bank itself.

- The presence of and Rahn Tasjily based National Sharia Board Fatwa Indonesian Ulama Council, should be a source of law is the special treatment for binding guarantees on Islamic banking, especially the binding guarantees the rights to land.

- It is expected that Rahn agreement as an agreement binding guarantee of the rights to land for Islamic banking and PPAT also be authorized to make them fulfilled the certificate of authenticity, and the authority was established by a legislation in order to obtain legal certainty. This is as the agreement of grant has been authorized to make and agreement PPAT Grant is also an agreement which is based on Islamic law.

\section{References}

[1] A. Basyir 2005 Hukum Islam tentang Riba Utang-Piutang Gadai dikutip dari Sasli Rais Pegadaian Syariah: Konsep dan Sistem Operasional Suatu Kajian Kontemporer Jakarta: UI-Press

[2] Boedi Harsono 2008 Hukum Agraria Indonesia Sejarah Pembentukan UndangUndang Pokok Agraria Isi dan Pelaksanaanya Jilid 1 Hukum Tanah Nasional Jakarta: Djambatan.

[3] Budi Untung 2011 Kredit Perbankan di Indonesia Second Edition Yogyakarta: Andi

[4] Habib Adjie dan Muhammad Hafidh 2014 Akta Perbankan Syariah yang Selaras Pasal 38 UUJN-P Edisi Revisi First Edition Semarang: Pustaka Zaman

[5] Salim HS. 2004 Perkembangan Hukum Jaminan di Indonesia Edisi Pertama Cetakan Pertama (Jakarta: Raja Grafindo Persada

[6] Sutan Remy Sjahdeini 1999 Perbankan Islam dan Kedudukannya dalam Tata Hukum Perbankan Indonesia First Edition Jakarta: Pustaka Utama Grafiti.

[7] Tim Penyunting Erlangga 2014 Himpunan Fatwa Keuangan Syariah Dewan Syariah Nasional MUI Jakarta: Erlangga

[8] http://www.khafidzt.ga/2015/03/92dsn-muiiv2014-pembiayaan-yang-disertairahn.pdf Access the July 282016. 